\title{
Religious Indoctrination or Marginalization Theory? Muslim-Christian Public Discourses and Perceptions on Religious Violence in Kenya
}

\author{
Hassan J. Ndzovu
}

\section{Abstract}

The numerous killings of non-Muslims by Muslim jihadi groups in Kenya, have fuelled ethno-religious tensions manifested in hatred and anger against the entire Muslim community. Though anti-jihadi Muslims have rightly condemned the targeting of their non-Muslim countrymen by the jihadists, the Christian leaders have not been satisfied by their counterpart's internal self-criticism. There are suspicions from Christians, even when anti-jihadi Muslims disassociate themselves from the heinous criminal acts of the jihadists, that all Muslims are the same, and posing a threat to peace in the country. In this context, there has arisen two theories of why we do have jihadist Islam in Kenya, and, for that matter, in other parts of the world. The one argument is that it is due to the social and economic marginalisation and exclusion of Muslims from the dominant and governing hegemony of the mainly Christian-affiliated parties in the country. This causes discontent and dissatisfaction among Muslims, especially among the poor and underprivileged, with the result of their radicalisation, attraction and exposure to, the jihadi groups. The other argument, and this coming from the Christian side, is that Muslims are not the only ones economically marginalized in the country. For them, one of the main factors for the radicalisation of some Muslims and their joining of jihadi groups, is the indoctrination by charismatic Muslim leaders (imams). Foregrounding the potency of both these accounts for explaining why some Muslims join the jihadi movement, as well as why we have jihadi violence (especially against Christians in 
Kenya), this article addresses these two theories and attempts to point to a way forward. It shall also address the issue of public rhetoric emanating from Christian religious leaders, against Muslims.

Keywords: Jihadi, Muslims, Christians, marginalization, radicalization, Kenya

\section{Introduction}

With the deployment of the Kenya Defense Forces (KDF) into Somalia in 2011 to pursue members of al-Shabaab, incidents of religious-based violence ascribed to jihadi groups have increased in the country. It appears that religious radicalization of some Kenyan Muslims is becoming endemic, especially in the predominantly Muslim-inhabited areas in the country, viz. the coast and the north-eastern regions. Several Muslims from these areas have in recent times been indicted for their alleged links with al-Shabaab and other jihadi groups. It is alleged that these Muslims, and those similarly minded, pose a great danger to the plural Kenyan society, due to their exclusivist ideology. It is in this context, that this article aims to examine the divergent views of Muslim and Christian leaders, with regard to their public pronouncements, and perceptions of occurrences of purported religiouslybased violence against non-Muslims in Kenya, as these are attributed to the jihadi groups. To the Muslim leaders, economic marginalization and the inequitable distribution of resources rouse discontent and dissatisfaction among Muslims, which vulnerably expose different categories of Muslims to the jihadist emancipation call. To Christian leaders on the other hand, Muslims are not the only ones economically marginalized in the country. For them, one of the main factors for the radicalisation of some Muslims and their joining of jihadi groups, is the indoctrination and ideological agitation of socalled 'radical Islam' by charismatic Muslim leaders (imams).

\section{Background and Context}

Between December 2013 and November 2014, a group of Muslims, affiliated to the jihadi Muslim faction, took control of certain mosques (Musa, Sakina, Swafaa and Mina) in Mombasa to serve as centres for preaching their 
ideology and brand of Islam (Jumbe \& Beja 2013; Igunza 2014). While breaking up and dispersing a 'jihad convention' in Mombasa, the police raided Masjid Musa (renamed Masjid Shuhadaa) in February 2014, and allegedly recovered a gun, machetes, laptops, al-shabaab flags and other 'militant' training materials from the mosque (BBC News, February 2014). A month later, two gunmen raided Jesus Joy Church in the coastal city, killing seven people and injuring several others (Bocha 2014). By the end of November 2014, sixty-four Kenyans had been executed in a Mandera attack, targeting non-Muslims living in the region (Mohammed 2014). Coupled with other incidents of attacks targeted at non-Muslims ${ }^{1}$, Christian leaders have rejected the argument of economic deprivation, insinuating religious indoctrination by charismatic leaders as a factor driving some Muslims joining the jihadi movement.

These attacks have, undoubtedly, raised anxiety and the level of religious tension in the country, with Christian Church leaders feeling vulnerably exposed to the exclusivist jihadi ideology (Deacon et al. 2017). With increased cases of violence attributed to the jihadists, issues of religious radicalisation, certain Islamic concepts, mosque management, and imams' religious sermons have become subjects of scrutiny and concern for the general Kenyan public (Abdulahi 2014). One can even say that there is a quiet rage simmering among Christians, against Islam, as illustrated in some of the comments by a section of Christian clergy. Some of these Church leaders even make blanket statements, declaring the entire Muslim community as enemies of the Christian faith (Mbogoh \& Karanja 2014), thereby undermining efforts of mutual interaction in a plural society. This view of a group of Christian Church leaders runs counter to the one espoused by the anti-jihadi Muslim clerics who call upon their non-Muslim counterpart to join them as partners to dialogue and reflect together in defeating religious radicalization.

The jihad doctrine remains an issue that has attracted intense debate among both Muslims and non-Muslims on the meaning, scope and purpose of the concept ${ }^{2}$. In essence, at the individual level, jihad means one's inner

\footnotetext{
${ }^{1}$ In April 2015, several students at the Garissa University College were in one of the gruesome incident of terror in Kenya.

${ }^{2}$ Cf. Dangor's 'Jihad: between War and Peace' (2005), for a thorough intraIslamic Studies analysis.
} 
struggle to lead a righteous life in accordance to God's commandments. On the other hand, at the collective level, jihad could take various forms that include the physical jihad, which call upon Muslims to raise arms and defend themselves against aggression. It is this understanding of jihad that is employed in this article. Due to the problem of interpretation, the physical jihad has erroneously been stated to refer to a 'holy war' declared by Muslims against non-Muslims (Zawati 2015; Rubenstein 2010; Firestone 2004). Consequently, in this article, jihadi (distinct from jihad) refers to those groups of Muslims who uses physical violence and aggression to establish an Islamic state thereby threatening stability of their respective countries (Elischer 2015). The jihadi movement in Kenya is a conglomeration of groups that espouse a violent form of jihad discourse in the country. Though these groups are affiliated to al-Shabaab, they sometimes operate independently and they include the al-Hijra, Jaysh Ayman and al-Muhajiroun groups.

Most of the studies done on the subject of 'religious violence' present the thesis that there is a strong interplay between religion and conflict, a view utterly rejected by Ronald E. Osborn. In his critique, Osborn argues that the framing of conflict as 'religious' is a political project with a specific historical foundation, which discloses and obscures the nature of social violence. Osborn stresses that the terms used in the construction of 'religious violence' might as well be applied in reference to violence initiated by 'secular' nation-states (Osborn 2014). Richard Jackson expresses similar ideas, arguing that the phrase 'Islamic terrorism' is a contested and politicized term influenced by dominant narratives. Jackson is of the view that 'Islamic terrorism' is a socially constructed idea intended to advance 'discrete political projects and reify a particular kind of political and social order' (Jackson 2007). Apart from this refutation of the connection of 'religion and conflict', 'religion and terrorism', other studies on the subject in Africa have focused on addressing the question: What makes people susceptible to the violent extremist ideology of the jihadi groups?

In answering this question, Anneli Botha (2013) identifies the root cause to this phenomenon of religious violence to be embedded in domestic or local conditions, which are often exploited by the jihadist leaders to recruit new followers. And, within the Kenyan context, Botha (2013) is of the view that it is primarily the 'socioeconomic, political, religious, national identity, counter-terrorism and internal/personal factors' that are the major drivers that 
draw people 'into radical groups'. Similar views are shared by Ioannis Gatsiounis (2012), William Rosenau (2005), Hassan Mwakimako and Justin Willis (2014). While examining cases of violence evident on the Kenyan coast, Mwakimako and Willis (2014) argued that the resultant violence evident in the region 'is the consequences of the profound inequalities of Kenya's political system, as much as of international Islamic radicalism. Those who are involved in the violence have pulled these multiple strands together'.

Clearly evident in these studies is the ascribing of plural-causal theory to the phenomenon of religious violence in Kenya, a trend that is also evident in other parts of Africa. In exploring the attraction to Boko Haram, a jihadi group operating in Northern Nigeria, William Hansen (2016) maintained, 'In the case of Boko Haram there are multiple factors that one needs to consider; some of them religious, some (especially) cultural, some ethno-linguistic, some even psychological.... There are, indeed, multiple factors involved'. Despite assigning a multiplicity of factors to the phenomenon in Kenya, Rosenau (2005), though, concludes that religious extremism has failed to take strong root in the country, a situation that has currently changed as evident in recent events and studies.

Contrary to looking at causal socio-cultural factors that radicalise some Muslims as briefly shown above, Sarah Feuer (2016) addresses the interventionist and solution aspect to the phenomenon of religious violence, by examining the involvement of Moroccan and Tunisian institutions of state Islam in combating violent extremism. Her study focuses on the perceptions of religious leaders on violence, which frame the public discourse on the subject in a non-violent register, for their followers in the respective countries. On her part, Angela Rabasa (2009) proposes various effective long-term solutions to the emerging trend of violence attributed to 'radical Islam' in the East African region, of which only three touches on the marginalization and religious indoctrination perspectives themes addressed in this article. The purposively identified three solutions advanced by Rabasa (2009) include: (i) Deter external support of radical groups operating in East Africa; (ii) reduce the influence of foreign Islamist organizations by identifying mainstream and Sufi Muslim sectors and helping them propagate moderate interpretations of Islam and delegitimize terrorism; and (iii) begin to remove barriers to economic growth in order to promote economic opportunity and thereby reduce the pool of potential jihadi recruits. 
Despite the fact that both the religious indoctrination and the various forms of marginalization have driven some sections of Kenyan Muslims into joining jihadi groups, it appears that Christian and Muslim clerics inside Kenya, seem to only emphasize one side of the argument - either the socioeconomic causes or the indoctrination argument - and ignoring the other. These are the two main focuses this article explores in detail. In order to address them systematically, the article addresses the following questions consecutively:

- How do the Muslim religious leaders frame the argument for marginalization and discrimination as reasons for the phenomenon of religious violence in the country?

- How do Christian clergy frame the argument for religious indoctrination and exclusivist preaching of the Jihadists, as causes for the religious violence in the country?

- How do the Muslim clerics' self-criticism manifest? and,

- How is the public rhetoric of both Christian and Muslim clergy to be understood in the context of jihadi violence?

In order to address these questions, I use framing theory, as advanced by Gitlin (1980), De Vresse (2005) and Jackson (2007). According to T. Gitlin (1980) 'framing' comprises of the production of 'persistent patterns of cognition, interpretation, and presentation, of selection, emphasis and exclusion by which symbol handlers routinely organize discourse'. In other words, framing is concerned with the presentation of an issue by emphasizing the importance of a specific aspect of the same subject (De Vresse 2005). As is demonstrated in the subsequent sections, the Muslim and Christian religious leaders selectively produce specific patterns in terms of which the phenomenon of jihadi violence is thought about, interpreted, and represented. In so doing, they select a certain number of impressions, perspectives, and representations, and emphasise these, at the cost and exclusion of others. These can be grouped in terms of either a theory that religious violence is the result of indoctrination, or that it comes about due to radicalisation and socioeconomic marginalisation. Both camps, in fact construct a narrative that frames the phenomenon, and, as such, appears mutually exclude the one from the other. Drawing on Jackson (2007), it is my objective in this research, to 
problematize these two framing narratives (of the phenomenon of religious violence), through the prism of discourse analysis. The article will demonstrate 'the politics of representation' at work with regard to this phenomenon, and also problematize the presumed intentions of embracing one specific 'mode of representation over another' rather than another (Jackson 2007).

\section{The Marginalization and Discrimination Argument by Muslim Clerics}

Economic injustices against sections of the Kenyan Muslim population are deep-seated historical injustices, and a sense of marginalisation among the community exists. It is suggested that this condition, provides a fertile ground for the mobilisation of domestic jihadi groups, like the al-Hijra, Jaysh Ayman and al-Muhajiroun, to perpetrate criminal acts and different forms of atrocities on especially non-Muslim civilians. In addition, they are supported by the al-Shabaab movement, which endeavours to regionalise and localise its violent jihad discourse. Perceptions of marginalization has fostered a favourable environment for spreading jihadi ideas among sectors of the Muslim community in Kenya. The demographic concentration of Muslims on the Kenyan coast and the north-eastern regions, means that it is also here, that we find an aggregating of Muslim discontent with government. These areas are severely marginalised in government development projects, and it is here, that Muslims experience the most acute forms of deprivation and destitution. Over the last two decades, this perception has escalated, in so far, in the words of (Ochiel 2015), Muslims here 'feel increasingly marginalised, with the government's promises of equitable development', being broken. Such sentiments insinuate that certain groups of Kenyan Muslims are attracted to the jihadi movement as a result of economic frustration.

Because of this viewpoint Muslim leaders have suggested that it is crucial to improve the living standards in regions predominantly inhabited by Muslims, the coast and the north-eastern areas, which generally have a higher incidence of poverty than other regions (Njonjo 2013). The concern is that those segments of the Muslim community that feel disadvantaged are more susceptible in enlisting into the jihadi groups. The Muslim residents of these regions have continuously complained of fewer access to land and jobs, than 
upcountry people where the majority are Christians (Akwiri 2014). In their demands, Muslim leaders called upon the political leadership of the Kenyan government to,

address the drivers of radicalization and violent extremism, e.g. discrimination, unemployment, historical injustices, marginalization, corruption, harassment by police and other security agencies (e.a.; Standard Team 2015).

Although the Muslim leaders enlist numerous factors as drivers causing Muslims to join jihadi groups, they can be all summarised as factors that give rise to different forms of socio-economic and socio-cultural marginalization and discrimination. If we use De Vresse's(2005) distinction between the 'powerlessness' and 'responsibility' frames to analyse these sentiments and perceptions among Muslims, the powerlessness frame reveals that Muslims in these areas do not have any marked influence on the conditions in which they live. This is mainly due to the 'dominance' of political power, and therefore also socio-economic investment by upcountry Christians, in predominantly Christian areas and not Muslim areas. The reality is that the minority Muslims' condition in Kenya is appalling, forcing some of them into the jihadi movements. The flipside of this argument, is that, in terms of the responsibility frame, Muslims cannot be blamed for either their condition, nor the fact that some join the jihadi movements. The blame for religious violence, is then laid at the door of government, and the State, for failing to address the root causes of the various forms of marginalization and discrimination.

Moreover, reports have shown, that the rural economy of the coastal and north-eastern regions is in a state of collapse, a consequence of the adverse effects exacerbated by the ineffective governance of the postcolonial regimes (Njonjo 2013). Because of the economic deprivation, the impoverished category of the Muslim community explores opportunities to survive, which see them turning to the jihadi groups. And due to the seemingly relative success of their Christian compatriots, Muslims' resentment increases, fuelling ethno-religious-regional hatred, making religiously-based violence 'more attractive to the desperate and dispossessed' (Hansen 2016). In addition, the perception created by Muslim clerics is that the members of the jihadi movement in Kenya are always the unemployed 
sections of the community - those who suffer marginalization and discrimination. This underscores the finding of a 2009 study in Europe, that found that most of the jihadist members of jihadi groups in Europe, while well educated, middle class and well integrated individuals in European societies, were driven to jihadi acts by their 'perceived suffering of their brothers in the Islamic world' (Mutua 2015).

Similarly, after the gruesome attack on Garissa University in Kenya in 2015, where 148 people were killed, and 79 more injured, one of the perpetrators was identified as Abdirahim Abdullai who was a young and educated individual described as a brilliant promising lawyer. Upon completion of his law degree studies, the young man from a middle level family had allegedly secured employment with a local bank as a legal officer (Mutua 2015). The other is Ahmed Ayman, a former engineering student at Jomo Kenyatta University of Agriculture and Technology (JKUAT) believed to have been recruiting Kenyan Muslims into the jihadi movement operating both in Kenya and Somalia. And the last is the slain Luqman Osman Issa, accused of involvement in jihadi activities, who held a Business Administration degree from a Ugandan university, and was regarded to be the commander of Jaysh Ayman, a jihadi group active at the Kenyan coast, and supposedly formed in 2001 with the assistance of Sheikh Aboud Rogo (Standard Team 2015). These facts confirm that not all members of the jihadi groups are necessarily drawn from economically marginalized segments of the Muslim society. But, just because one has a university degree, comes from a middle-class family and has secured employment, likewise does not stop one from sympathizing with the majority poor and marginalised. The support for the jihadi movement emerges because of the fact that it speaks to the views of many Muslims who feel ignored by the postcolonial political leadership dominated by upcountry Christians. The occasional involvement, therefore, of the privileged segment of the Muslim community in the activities of the jihadi movement does not disprove the marginalization theory, since, it appears that it is driven by fellow Muslim identification with the poor and marginalised.

That stated, though, the fact is that the majority of the jihadists are people who are unemployed or unemployable, and who are voluntarily joining the violent movements. Due to their sense of frustration, marginalization, and alienation, many of these individuals feel that 'their hopes and chances in life have been taken away from them' and hence the 
only alternative left for them, is the allure of a good life presented by these movements (Ng'ulia 2015). Even so, while it is true that many of the members in the jihadi movements could be from poor backgrounds, it is also a fact that that the majority Muslims in Kenya, who find themselves living in the same conditions, with the same frustrations, have chosen not to associate with groups that advocate violence (Karega 2015). This means that there are other factors at play that attract people to joining the jihadi groups. And according to the Kenyan Christian clergy, the desire to joining these groups is 'primarily' driven by religious propaganda and indoctrination by charismatic leaders.

\section{Religious Indoctrination and Exclusivist Preaching of the Jihadists: Christian Clerics' Views}

Within the Kenyan context the appearance of jihadi ideology could be traced to the influx of Saudi Arabia-trained-local and expatriate preachers at the turn of the century who gradually took over mosques and madrassas in the Coast and North-Eastern regions. The preachers from Pakistan, Yemen and other countries were funded by Saudi Arabia and introduced a Wahabi-Salafi form of Islam that, among other beliefs, rejected co-existence not just with other faiths, but also with divergent factions of the Islamic faith (Gaitho 2015). Through their madrassas and the mosques, they served as centres for propaganda, indoctrination and recruitment that emphasized that the central message of the jihadi ideology is a struggle of a religious nature, which has to be won in order to defend the faith that is being threatened (Karega 2015). In their exclusivist sermons addressed to Kenyan Muslims, these preachers proclaimed the fighting against all those who were not of their own persuasion for the alleged danger they pose to Islam, and that they should be defeated in battle.

In addition, the conceptualization of non-Muslims, as well as those Muslims who do not support their ideology, as unworthy human-beings and 'enemies', provided the ideological leverage to preach against those who were supposedly the source of 'suffering', and the bedevilling of the general Muslim community in Kenya. The cultivation of related attitudes provided the justification for various acts of aggression against non-Muslims, such as the Westgate siege (21 September 2013), the Mandera bus incident (22 November 2014) and the Garissa University College attack (2 April 2015). In 
all these jihadi onslaughts, the jihadists' targets, were non-Muslims, who they dehumanized and portrayed as oppressors, and 'disbelievers'. Once warmongerers believe that fellow human beings are not human, they can be activated for the attack and killing of the perceived 'enemy' (Karega 2015). All the victims of the jihadists' violence were required to prove their faith by reciting the shahada (the proclamation of faith), failure to which, they were killed. In the process, those who were able to prove their Islamic faith by pronouncing the kalimat (declaration of faith) were spared their lives. Clearly, this shows that there is a religious motif behind the violent attacks of the jihadi groups as they openly assert to be advancing the cause of Islam by sparing Muslims who can recite the declarations of faith (Oginde 2015).

Due to these facts, a section of the Christian clergy in Kenya has come to the conclusion that it is not marginalization that drives some Muslims into joining the jihadi movements, but rather the brand of Islam being propagated by their clerics. This viewpoint is typical of a specific genre of anti-jihadi movement Christian scholarship, produced by Church leaders in Kenya. Within Islam, there is no doubt that religious identity and loyalty to the faith, have been confirmed, to be powerful instruments for the mobilization of jihadis as well as for propagation, inspiration, and the validation for the actions of the jihadi warriors (Hansen 2016). According to Botha's (2013) study, around 87\% of Muslim youths who joined the alShabaab movement (read, jihadi groups) was due to 'religious' reasons while only $4 \%$ were influenced by economic reasons, confirming the concerns of the Christian clergy. But such figures as indicated in the above study should be interrogated and not taken at face value.

A careful interpretive analysis of the jihadi groups' literature reveals that their major concerns are not religious, but political, and, that their use and application of religious symbols in their propaganda, is merely 'instrumental rather than primary' (Jackson 2007). Although the jihadists' discourse is frequently expressed in religious language, it should be viewed as a variety of 'secular or nationalist protest at external and internal domination and forms of exclusion' thereby espousing a revolutionary ideology (Jackson 2007). For instance, the literature and videos produced by al-Shabaab suggest that the movement is pursuing clear political goals, including: support for the establishment of an Islamic state in Somalia; ending non-Muslims 'occupation' of so called 'Muslim land' in Kenya; and supporting local jihadi insurgencies in Kenya (Hussein 1434; Press Office 
1434; Video, 'Mpeketoni'; Rogo sermon 2012.) For the jihadists, therefore, religion is significant, but only as part of a whole ideology that seeks to verbalise and channel certain local political grievances.

Furthermore, despite the Christian clergy's denial of the marginalization theory as the attraction into joining jihadi groups in Kenya, it is a fact that the vast bulk of the jihadists come from the poor, destitute, and the dispossessed segment of society. As pointed out earlier, it is the conditions in which the poor live, that gives rise to discontent, and also provides the milieu in which the jihadi movements recruit the majority of its militant supporters -from the poor and impoverish underclasses. This is because to them (the destitute), Islam represents a call to justice, and a return to the glorious past. This is an appealing message to those who are dispossessed and struggle to survive. As victims of perceived marginalization attributed to an oppressive system of politics and governance, the destitute amongst the Muslims readily find consolation in religion, and turn to it, to seek justification for their revolutionary ideas and practices.

\section{'Slaying the dragon of terror': Muslim Clerics' Self-Criticism}

Though the Christian clergy have been vehement in advancing the religious indoctrination argument as the cause for religious violence in the country, the Muslim clerics have been hesitant to embrace this point of view. Despite their reluctance, Muslim clerics are aware of the existence of the jihadists amongst the Muslims and the danger their activities pose to the community. Meeting under the auspices of the Council of Imams and Preachers of Kenya (CIPK) on 13 June 2015, Muslim clerics were concerned that the activities of the jihadi movements were greatly affecting the economy and education of the North-Eastern and Coastal regions, which are predominantly inhabited by Muslims. The clerics lamented:

[The] hotels have closed in the Coast which has led to massive job losses for our people. The schools in Northern Kenya have also closed, which means our children cannot go to school. Time has come for us to slay the dragon of terror since it is we the residents from these regions who are suffering in the end (Maichuhie 2015).

Though Muslim leaders have insisted that their communities have been mar- 
ginalized economically, they were worried that the activities of the jihadists would worsen the situation by affecting the education sector and the tourism industry. What could the Muslim clerics have meant by 'slaying the dragon of terror'? Possibly, it implied inner criticism, which the clerics have been unwilling to engage.

Following numerous incidents of jihadi violence against nonMuslims the Supreme Council of Kenyan Muslims (SUPKEM) pledged to begin vetting preachers and what they teach in the madrassas, in order to tame the 'radicalization' of Muslims. The SUPKEM, consequently, unveiled its 'emergency programme' to analyse the attraction of some Muslims into joining the jihadi movements that are blamed for the various acts of violent murder in the country. In this regard, Adan Wachu, the SUPKEM Secretary General, said that,'We will be putting all our imams and preachers...to speak with one voice with the view of taking inventory of all mosques and madrassas', adding that the new measures will be able to identify the imams involved in the recruitment of fighters for the jihadi groups (Mutambo 2015). This declaration seems to also tacitly acknowledge the religious indoctrination perspective by initiating efforts to counter the message of the jihadi clerics who supposedly 'distort' the Quranic message, in their justification of violence. The SUPKEM strategy, however, seems to be unrealistic, given that madrassas in Kenya do not have a regular syllabus, making it difficult to monitor what individual madrassas teaches. The teaching of the Quran's recitation, the Seerah (biography of Prophet Muhammad), and hadith (sayings of Prophet Muhammad), nonetheless, form the core of the syllabus, which is susceptible to different interpretations based on sectarian affiliations.

In a statement that embraces religious pluralism, Muslim leaders through the Majlis Ulamaa Kenya (Council of Muslim Scholars of Kenya) implicitly cautioned their co-religious clerics asserting:

To fellow religious leaders, remember that you have been entrusted with the sacred duty of providing spiritual nourishment to humanity. This includes using divine teachings to guide humans on how to live peacefully with fellow human beings. It is your duty to correct misconceptions about religion, guide humanity and inculcate in them the virtues of peaceful co-existence (Ismail 2015). 
Clearly, anti-jihadi Muslim clerics are aware that the jihadi movements' intentions are to stir religious conflict in the country (Jamah 2015). Consequently, they applauded the Christian leadership, for their patience and understanding of the jihadists' agenda. And in a show of solidarity, the antijihadi Muslim clerics organized, (i) fundraising to contribute towards burials and medical cost of the jihadists' victims; (ii) arranged blood donations in various centres; and (iii) vowing as imams to use the pulpit and other community infrastructure to counter extreme and violent religious ideas (Naado 2015). They underscored their commitment to countering religious extremism, insisting that if the drivers of religiously-based violence are not adequately tackled, then they create a fertile ground for recruitment to the jihadi groups (Naado 2015).

Worried that the numerous killings of the jihadists would divide the country on religious lines, the Majlis Ulamaa Kenya (Council of Muslim Scholars of Kenya) also released a statement in a local daily, which in part stated:

A Muslim is not only ordered to respect human life, but even the life of other creatures of God. Throughout human history religion has been misused by various groups as a basis of perpetuating violence, and thus becomes a very significant pull factor. For over 150 years Muslims, Christians and people of other faiths have peacefully and harmoniously co-existed in this country (Ismail 2015).

Views and statements such as these show that Muslim religious leaders in Kenya are not only very aware of the potential conflicts jihadi propaganda pose for the country, but also that they have been acting pro-actively to stem the tide of jihadi propaganda. This is evident in their push for the study of what is being taught in mosques and madrassas, as well as their active discouragement of Muslims to join the jihadi groups. In addition, they have also initiated campaigns and drives on behalf of the victims of jihadi violence. Yet, they are of the opinion, that, despite their concerns and efforts to counter the jihadis' ideology, the government have disappointed them. It has even gone as far as to accuse the anti-jihadi clerics, to be supporting the jihadists (Jamah 2015). These and similar State allegations have been very demoralizing for Muslim leaders who oppose jihadi ideology. They feel that the continuation of these kinds of accusation, show that their efforts are 
unappreciated. To them, the continuation of such accusations, actually reveals the State's prejudicial perception and treatment of the Muslim community, viz. to see them as enemies rather than allies and partners against violence. As such, the State is in fact alienating members of the community who feel that rather than appreciation for their efforts, they are being targeted by the State because of their faith (Jamah 2014). Such blanket perceptions and generalised opinions are also found among a considerable section of the Christian clergy, as is shown below.

\section{Ethno-Religious-Regional Tensions: Blanket Condemnations of the Muslim Community}

After the horrific massacre of thirty six Christian quarry workers in Mandera on 22 November 2014, plans were made for 'revenge' killings of SomaliMuslims by residents of the region (Chaka) where many of the victims hailed from (Kiai 2014) ${ }^{3}$. Strongly condemning the killings of fellow Christians, the locals organised protests, also asking, 'how would they [Somali-Muslims] feel if we stopped the vehicles and asked the non-Christians to return to Garissa, Mandera, Dadaab or any other part of Northern Kenya?' (Ngoolo, 2014). Clearly, the killing of Christian civilians has added to ethno-religiousregional tensions. Some, at this point only verbally, pose the question as to revenge attacks, and that, against an entire community. This, and similar outrages by a section of Christians in the country, suggest a growing resentment against a generalised understanding of what Islam stands for violence, and not peace. Yet, the violence is not supported, nor condoned by the vast majority of the Muslims in Kenya - only by a small minority, and that, mostly due to socio-economic discontent as pointed out above.

Another element to this matter, is that the National Council of Churches of Kenya (NCCK) allege that, for the last decade Christians and Churches in Kenya have been subjected to relentless verbal attacks by Muslim preachers. According to them these attacks were intended to emotionally mobilize Muslims against Christians. The church leaders are concerned that the verbal abuse and mobilization has in the recent years been accompanied by armed violence targeting Christian pastors, worshippers and

${ }^{3}$ The workers were killed because they could not recite the shahada. 
the destruction of churches. And, to confirm a conspiracy theory, some Christian clergy accused their Muslim counterparts of failing to condemn the violent attacks, suggesting tacit approval for these attacks by them (Mbogoh \& Karanja 2014). The allegedly conspiracy against Christians by Muslims is captured in the words of Rev. David Oginde (2014) stating,

It is sad but the Muslim fraternity has been nonchalant in their support of government in the fight against terrorism. When the counter-terrorism Bill was tabled in Parliament many years ago, they fought it tooth and nail until it was totally diluted. Whenever terror suspects have been arrested, this religious community has often come out in strong public defence demanding their unconditional release.

Rev. Oginde further added that when security forces storm into mosques accused as 'radicalization' centres of the jihadists, both religious and political leaders from the community strongly criticized 'the government for highhandedness, and defilement of places of worship' (Oginde 2014). The Christian leaders argued that, ironically, the same passionate condemnation 'is rarely seen when innocent Kenyans are massacred' by the jihadists (Oginde 2014). Emerging from the Church clergy's public discourse is that, while Muslim leaders have rightly condemned the indiscriminate arrests of Muslims, the extra judicial killings and the storming by security agents into mosques purportedly linked with jihadi groups, Church leaders feel that the Muslim clerics have not used the same zeal in condemning religious based violence of the jihadi movement.

And this is why, in an absolute attack of the Muslims clerics, the NCCK was categorical:

...we have come to the conclusion that we have either been dealing with Muslim leaders who have no power or grip over their faithful, or they are conspirators who are dishonest and economical with the truth regarding the radicalization and mobilization against Christians. This is especially so in the light of the strong words Muslim leaders use to defend mosques where radical literature and weapons have been found. How do weapons get into mosques without the leaders' knowledge? (Mbogoh \& Karanja 2014). 
The Church leaders' sentiments, undoubtedly, seem to be drifting toward blanket accusations and declarations of the entire community as enemy, rather than partner to dialogue with, in defeating violent religious extremism. And, in further showing their distrust and dissatisfaction with the Muslim religious leaders, the NCCK stated:

Christians do not now trust the prompt press statements by Muslim leaders dissociating themselves and the Islamic faith from the terror attacks every time one happens. The leaders have never presented any evidence that they have ever taken any action to pre-empt and prevent such attacks on Christians before they happen (Mbogoh \& Karanja 2014).

The NCCK statement was a clear public ridicule of Muslim clerics, who, in their opinion, regarded the Muslim leadership of the country, as part of the conspiracy against Christians. This official position of the Church leaders was certainly dangerous, particularly when it was affirmed with the warning that 'Muslims live everywhere in Kenya and in some locations there are only a handful of them .... It is therefore in their interests to reverse the anger being built up in the church' (Mbogoh \& Karanja 2014). In addition, the Church leaders declared that the patience of Christians was running out and as a consequence, 'retaliatory attacks may become a real possibility' (Mbogoh \& Karanja 2014). It is not clear what the NCCK intended with such statements - were these threat, or incitements of indiscriminate violence against the Muslim community? (Dolan 2014). Even so, by their statements, these Church leaders affiliated to the NCCK, are falling into the jihadists' trap. They are intent on provoking a religious war in Kenya ${ }^{4}$. Clearly, the

${ }^{4}$ Different from this trend, we need to mention the view of the Catholic Church head in Kenya, John Cardinal Njue. As a section of the Christian population contemplated staging retaliatory attacks against Somali Muslims, and the NCCK threatened the Muslim community of possible reprisals if the jihadists do not cease from attacking non-Muslims, he called on Christians to maintain peace, and refrain from conducting revenge attacks even though the activities of the jihadi groups have demonstrated 'patterns of religious intolerance'. These views were also supported by other Church leaders, such as Canon Francis Omondi, who appealed to the government to resolve the 
Christian clergy present and explain the subject of religious conflict in the country within the prism of De Vresse's (2005) 'moral frame', indirectly attributing jihadi violence to a generalised prejudice against Islamic morality and religion. This particular form of framing interprets the various incidents of attacks attributed to the jihadists, in the context of religion, and not politics.

Perhaps, the indifferent approach attributed to the anti-jihadi Muslim clerics in condemning the activities of the jihadists could be due to the uncertainty about their own security (Ochami 2015). The Council of Muslim Scholars expressed this concern stating:

Contrary to the impression that has been created, we as Muslim scholars have been tirelessly working through various religious institutions and forums to address radicalization, the threat of terrorism and other crimes. We have even lost some of our members while others have been threatened (Ismail 2015).

Several incidents of the killing of the anti-jihadi Muslim clerics have been witnessed in different parts of the country, creating fear amongst them and explaining their unresponsive and neutral attitude towards the jihadi movement. Such statements, however, demonstrate that even though there are sections of the Muslim population that subscribe to the jihadi ideology, the majority of the Muslim community in Kenya practice a form of Islam that embrace tolerance and pluralism in society. That their critique of the jihadi ideology may not always be as verbal as many wish, may be attributed to the fact that they themselves fear for their lives, if they or too visible in their criticism and denunciations of the jihadi ideology.

\section{Conclusion}

This brings me back to my earlier question: Why do Muslim and Christian clerics hold divergent views with regard to the causes of religiously-based violence in Kenya? To the Muslim clerics it is easier to blame the external (State) than to, though reluctantly, advance the religious indoctrination

issue of insecurity since it was gradually creating religious divisions in the country. 
perspective, which sometimes is erroneously interpreted to insinuate that Islam itself, is the problem. By advocating the marginalization argument, their narrative is one of deprivation and poverty, and that these conditions provide the fertile milieu for the propagation of the jihadi ideology, and the recruitment of discontented Muslims. Moreover, since there is no strong and overt strategy by the State to change the living conditions of the coastal and north-eastern regions of Kenya where most Muslims live, it appears that government in fact discriminates against the Muslim community in Kenya. There is evidence that Muslims' regions of the country are among the poorest and least developed areas, leading Muslim leaders to interpret this disparity as discrimination and deliberate indifference of the State. Symptomatic of this state of affairs, and of assumed indifference and discrimination, we may also mention Muslims' perceptions of the difficulties to acquire documents of citizenship by certain segments of the Muslim society, the relatively few Muslims in government appointed positions, and a lack of the accommodation of the political aspirations among Muslims in the country.

From the perspective of Christian clergy, there is the insistence that jihadi Islam is the result of religious indoctrination by the radical Muslim preachers. As demonstrated in the discussion, some Christian leaders have publicly associated Islam in general with the violent actions of the jihadists, thereby suggesting that violence and Islam go together. As pointed out, to some degree it is true that there has been militant Muslim preachers who have started to operate in Kenya since around 1980s. Yet, to rhetorically generalise and apply this perspective to all Muslims in Kenya, is wrong, if not malicious. Implicitly, it actually argues for the moral superiority of Christianity (above Islam), and discredits Islam as not being a religion of peace, but of violence. Brislen (2015) calls this kind of postering, which has undertones of religious rivalry in the public sphere, 'symbolic confrontation'.

We also looked at the Muslim clerics' self-criticism, and how, under certain implicit forms of threat, they have indeed taken a stand against jihadi violence. The research has also indicated that the explicit preaching and teaching against all forms of violent jihad, and even the clerics' thrust to have the sermons and teaching in mosques and madrassas assessed as to whether they convey messages of violence, is to be appreciated. So too, are their explicit condemnation of jihadi violence and their dissociation of the general Muslim community with the message of the jihadis.

Finally, the operations of the jihadis in Kenya - as well as elsewhere 
on the continent - should not be seen primarily, in a religious frame. It has been pointed out that within the jihadi ideologies, it appears that religion itself, plays a very minor role. The main ideological content and intent is political, and this approach, uses religion to divide the population. As such, religious leaders should not be coerced into participating in religio-political contestations, and in choosing sides within a political framework. The religions should rather be alert to the fact that religion is often used to justify ideologies, and ideologically-founded violence against perceived enemies. They should counter charismatic preachers who exploit the weak points in society, such as historical injustice - with regard to socio-economic and political marginalisation - to advance their own political agenda among the community. Moreover, though there are a vast majority of Muslims who have not joined a jihadi group, this cannot be taken as evidence that they do not support the goals of this movement. To many Muslims, their shari' $a$ law also imply the establishment of justice, which includes abundant access to basic necessities of life. And since the jihadists' goal is to ensure the establishment of God's law on earth, and to guarantee justice, the vast majority of the economically deprived Muslims at the coast and north-eastern regions are likely to support the advocating and implementation of shari'a merely because of the expected security. To non-Muslims, this reality may be of concern, and threatens peaceful co-existence, especially given the conditions in which a search for such justice is sought.

Looking then, at potential causes of the violence and jihadi recruitments, it would be better if the religions, as well as the State focus on the elimination of all forms of socio-economic conditions that might be used to foster and instigate discontent. Rather than using rhetoric against one another - which may, in itself, foster intolerance and play in the hand of escalating the potential for jihadi conflict - it is incumbent on the religious formations to attend to the socio-economic improvement of the conditions of the poor and marginalised, whether Muslim, or Christian. Muslims in Kenya, and especially those living in the coastal and north-eastern regions, are not the only ones that are underprivileged, poor and marginalized. If poverty and marginalisation are addressed cooperatively, also involving and leveraging the State, it may yet prove vital not only for the reduction of the potential of jihadi conflict, but also for the peaceful co-existence of the diverse Kenyan population. 


\section{Reference}

Abdulahi, A. 2014. Iron Fist Rule will not Liberate us from Terrorists. Sunday Nation 14 December, p. 28.

Abu Hussein. Maswala Muhimu Kuhusiana na Jihad Somalia. Gaidi Mtaani 3, Rabi Al-Thani 1434: 7-8.

Akwiri, J. 2014. Why the Fight against Radicalization will Give Rise to More Resistance. Coast This Week 3-9 January 86: 3.

BBC News. February 2014. Kenya Terror Charges after Mombasa Police Raid Mosque. Available at: http://www.bbc.com/news/world-africa26013964. (Accessed on 15 June 2016.)

Bocha, G. 2014. Four Killed and 20 Injured in Likoni Church Attack. Available at:http://www.nation.co.ke/news/Likoni-Church-Attack-Mombasa/-/10 56/2254740/-/xqeh0pz/-/index.html. (Accessed on 15 June 2016).

Botha, A. 2013. Assessing the Vulnerability of Kenyan Youths to Radicalization and Extremism. Institute for Security Studies Paper number 245.

Brislen, M. 2015. Images in a Cracked Mirror - Muslim and Christian Perceptions of Each other in Kenya. Horn of Africa Bulletin MarchApril, 26,2: 9-15.

Dangor. S.E. 2005. Jihad: Between War and Peace. Alternation Special

Edition 2: 252 - 266. Available at: http://alternation.ukzn.ac.za/ Files/docs/12.3\%20SpEd\%202/14\%20Dan.pdf.

Deacon, G. et al. 2017. Preaching Politics: Islam and Christianity on the

Kenya Coast. Journal of Contemporary African Studies pp. 1 - 20. Available at: http://dx.doi.org/10.1080/02589001.2017.1287345. (Accessed on 25 February 2017.)

De Vresse, C.H. 2005. News Framing: Theory and Typology. Information Design Journal 13,1.

Dolan, G. 2014. Why NCCK Must Temper its Statements. Saturday Nation 06 December, p. 13.

Elischer, S. 2015. Autocratic Legacies and State Management of Islamic Activism in Niger. African Affairs 114/457: 577-597.

Feuer, S. 2016. State Islam in the Battle against Extremism: Emerging Trends in Morocco \& Tunisia. Policy Focus 145. Washington: Washington Institute for Near East Policy. 
Firestone, R. 2004. Jihad. Palmer-Fernandez, G. (ed.). Encyclopaedia of Religion and War. New York: Routledge.

Gaitho, M. 2015. Sobering Questions on Terrorism. Sunday Nation 28 June, p. 33.

Gatsiounis, I. 2012. After Al-Shabaab. Current Trends in Islamist Theology 14: 74-89.

Gitlin, T. 1980. The Whole World is Watching. Berkeley: University of California Press.

Hansen, W.W. 2016. Poverty and 'Economic Deprivation Theory': Street Children, Qur'anic Schools/ almajirai and the Dispossessed as a Source of Recruitment for Boko Haram and other Religious, Political and Criminal Groups in Northern Nigeria. Perspectives on Terrorism 10,5: 83-95.

Igunza, E. 2014. Tackling the Radical Muslim Youth of Mombasa. Available at: http://www.bbc.com/news/world-africa-30118119. (Accessed on 5 September 2016.)

Ismail, K.K. 2015. Message from Majlis Ulamaa Kenya on the Gariss University College Terror Attack. The Standard Monday, 20 April, p. 11.

Jackson, R. 2007. Constructing Enemies: 'Islamic Terrorism' in Political and Academic Discourse. Government and Opposition 42,3: 394-426.

Jamah, A. 2015. Clerics Launch Anti-Shabaab Campaign. The Standard Monday, 20 April, p. 16.

Jamah, A. 2014. Heavy-handed Counter-terrorism Tactics Added Pepper to Injury this Year. The Standard Monday, 29 December p. 3.

Jumbe, I. \& P. Beja 2013. Mombasa Imams Alarmed as Radicalised Muslim Youth Take Over Popular Mosques; Police Fear Moving in Might Anger even Moderate Faithful. Available at: https://www.standardmedia.co. ke/article/2000099262/mombasa-imams-alarmed-as-radicalised-muslimyouth-take-over-popular-mosques-police-fear-moving-in-might-angereven-moderate-faithful. (Accessed 3 September 2016.)

Kiai, M. 2014. Massacres in Mandera Prove we are a Long Way from Being Truly United. Saturday Nation 06 December, p. 13.

Karega, M. 2015. There is More to Terrorism than Poverty. The Standard Wednesday, 29 July, p. 13.

Maichuhie, K. 2015. Preachers Blame Fake Muslims for Attacks; Pledge to Back Terror War. The Standard Monday, 15 June, p. 6. 
Mbogoh, R. \& P. Karanja 2014. Christians Demand Real Action from Government and Muslim Leaders. National Council of Churches of Kenya, Press Statement. The Standard Friday, 28 November, p. 42.

Mohammed, A. 2014. 'Has Kenya Lost to Al Shabaab?' Available at: http://www.the-star.co.ke/news/2014/12/06/has-kenya-lost-to-al-shabaab _c1048556. (Accessed on 10 June 2016.)

Mutambo, A. 2015. Plan to Vet Islamic Teachers Proposed. Daily Nation Wednesday, 08 April, p. 5.

Mutua, P. 2015. Poverty not the Only Thing Driving Youth to Terrorism. The Standard Thursday, 09 April, p. 14.

Mwakimako, H. \& J. Willis 2014. Islam, Politics, and Violence on the Kenyan Coast. Observatory Note 4: 1-26.

Naado, H.O. 2015. Terrorists' Main Agenda is to Breed Inter-faith Conflict. The Standard Sunday, 05 April, p. 5.

Ngoolo, L. 2014. Protesters Raid Somali Hotel in Mwingi Demo. The Star Thursday, 04 December, p. 2.

Ng'ulia, T. 2015. How Kenya Can Stop the Radicalisation of its Young People. Saturday Nation 07 February, p. 10.

Njonjo, K.S. 2013. Exploring Kenya's Inequality: Pulling Apart or Pulling Together? Research Report, Kenya National Bureau of Statistics (KNBS) and Society for International Development (SID), pp. 1-42.

Ochami, D. 2015. Cables Claim Makaburi Plotted to Kill Preachers. The Standard 07 March, p. 6.

Ochiel, L. 2015. Adopt Truth Team Report and Effect Proposals to Win War on Terrorism. Saturday Nation 02 May, p. 11.

Oginde, D. 2015. We Must Confront the Religious Question in the War on Terror. The Standard Monday, 05 April, p. 3.

Oginde, D. 2014. Muslim Leaders May Hold Key to Counter-terrorism Bid. The Standard 30 November, p. 15.

Osborn, R.E. 2014. Does 'Religious Violence' Exist?: An Argument Against Essentialism with Particular Reference to the Conquest of the Americas. Politics and Religion 7,3: 568-589.

Press Office. Sheikh Aboud Rogo's Death: A Catalyst for Change. Gaidi Mtaani 3, Rabi Al-Thani 1434, p. 5.

Rabasa, A. 2009. Radical Islam in East Africa. Rand. Santa Monica: Rand Corporation.

Rosenau, W. 2005. Al Qaida Recruitment Trends in Kenya and Tanzania. 
Muslim-Christian Public Discourses and Perceptions on Religious Violence

Conflict \& Terrorism 28,1: 1-10.

Rubenstein, R.L. 2010. Jihad and Genocide. Rowman \& Littlefield Publishers, Inc.

Standard Team 2015. Slain Terrorist was Degree Holder. The Standard 18 June, p. 3.

Zawati, H.M. 2015. Jihad and International Relations. In Shah, N.A. (ed): Islam and the Law of Armed Conflict. Cheltenham: Edward Elgar.

Hassan J. Ndzovu Department of Philosophy, Religion and Theology Moi University Eldoret

Kenya ndzovuhassan@hotmail.com 